\title{
ОЦІНКА ПЕРЕБІГУ ВІДНОВНОГО ЛІКУВАННЯ ХВОРИХ ПІСЛЯ ПЕРЕНЕСЕНОГО ІНФАРКТУ МІОКАРДА З СУПУТНЬОЮ АРТЕРІАЛЬНОЮ ГІПЕРТЕНЗІЕЮ
}

\section{О.М. Притуляк}

\author{
Івано-Франківський національний медичний університет, кафедра внутрішньої медицини №2 \\ та медсестринства, м. Івано-Франківськ, Украйна, \\ ORCID ID: 0000-0001-5159-5209, e-mail:dr.oprytuliak@gmail.com
}

Резюме. На сьогодні серцево-судинні захворювання (СС3) $є$ актуальною проблемою в усьому світі. Згідно з даними ВОО3, смертність від ішемічної хвороби серця (IXC) становить 9,4 млн на рік або 16,5\% усіх випадків смертності. Захворюваність на IXC в Україні становить 1859,99, в Європейському регіоні - 807,76 на 100 тис. населення. Особливу увагу лікарів серед ССЗ привертає гострий інфаркт міокарда (ГІМ), пов’язаний зі значним поширенням та високим рівнем летальності серед осіб працездатного віку. Щорічно в Україні реєструють майже 50 тис. випадків IM, а смертність від цієї патології залишається високою. Від ГІМ помирають $30 \%$ пацієнтів, у той час як у країнах Заходу - 5\%. Останнім часом особливої актуальності набула проблема удосконалення надання невідкладної медичної допомоги хворим на ГІМ. Світові тенденції у цьому напрямку схиляються до більш широкого застосування тромболітичної терапії, інтервенційного та кардіохірургічного втручання. Ці питання потребують детального обгрунтування та аналізу для покращення умов надання медичної допомоги та зменшення летальності серед хворих з ГІМ. Найбільш ефективним методом лікування ГІМ є виконання ендоваскулярної реперфузії міокарда шляхом стентування інфарктзалежної коронарної артерії. Проведення ЧКВ сприяє вірогідному підвищенню фракції викиду лівого шлуночка, вірогідному зменшенню кінцевого систолічного об'єму, маси міокарда та індексу міокарда лівого шлуночка у порівнянні з хворими без проведеної реваскуляризації. Виконання ЧКВ поліпшує протікання, прогноз та перебіг післяінфарктного кардіосклерозу у хворих після перенесеного Q, QS інфаркту міокарда і тому має бути пріоритетним напрямком лікування таких хворих.

Ключові слова: гострий інфаркт міокарда, артеріальна гіпертензія, ремоделювання, післяінфарктний період стентування.

Вступ. Постановка проблеми та її зв'язок із важливими науковими та практичними завданнями. Нині серцево-судинні захворювання посідають провідне місце у структурі захворюваності населення, зумовлюють третину причин інвалідності, суттєво впливають на тривалість життя і його якість, на показники втрат життєвого потенціалу України. Приблизно половина летальних випадків від хвороб системи кровообігу зумовлюється інфарктом міокарда (IM) [3; 6; 7]. Зважаючи на це, реабілітація хворих після IM набуває важливого соціально-економічного значення. Вирішення проблеми запобігання або мінімізації виникнення ускладнень у результаті перенесеного IM, поліпшення якості життя цієї категорії хворих потребує пошуку нових науково обгрунтованих, безпечних і доступних реабілітаційних програм [4; 10].

Обгрунтування дослідження. На сьогодні серцево-судинні захворювання (СС3) є актуальною проблемою в усьому світі. Згідно з даними ВООЗ, смертність від ішемічної хвороби серця (IXC) становить 9,4 млн на рік або 16,5\% усіх випадків смертності. Захворюваність на IXC в Україні становить 1859,99 , в Європейському регіоні - 807,76 на 100 тис. населення [1]. Особливу увагу лікарів серед СС3 привертає гострий інфаркт міокарда (ГІМ), пов'язаний зі значним поширенням та високим рівнем летальності серед осіб працездатного віку. Щорічно в Україні реєструють майже 50 тис. випадків IM, а смертність від цієї патології залишається високою.
Від ГІМ помирають 30\% пацієнтів, у той час як у країнах Заходу - 5\% [2]. Останнім часом особливої актуальності набула проблема удосконалення надання невідкладної медичної допомоги хворим на ГІМ. Світові тенденції у цьому напрямку схиляються до більш широкого застосування тромболітичної терапії, інтервенційного та кардіохірургічного втручання. Ці питання потребують детального обгрунтування та аналізу для покращення умов надання медичної допомоги та зменшення летальності серед хворих 3 ГІМ. Найбільш ефективним методом лікування ГІМ є виконання ендоваскулярної реперфузії міокарда шляхом стентування інфарктзалежної коронарної артерії. Проведення ЧКВ сприяє вірогідному підвищенню фракції викиду лівого шлуночка, вірогідному зменшенню кінцевого систолічного об'єму, маси міокарда та індексу міокарда лівого шлуночка у порівнянні 3 хворими без проведеної реваскуляризації. Виконання ЧКВ поліпшує протікання, прогноз та перебіг післяінфарктного кардіосклерозу у хворих після перенесеного Q, QS інфаркту міокарда і тому має бути пріоритетним напрямком лікування таких хворих. На сьогодні доведено, що рання успішна реперфузія міокарда як фармакологічна (тромболітична), так і механічна коронарографічне обстеження 3 проведеною ангіопластикою та стентуванням, $є$ найбільш ефективною тактикою для покращення клінічних результатів у хворих з ГІМ. Як відомо, найближчий та віддалений прогноз у хворих з ГІМ, пов'язаний з розвитком ГСН, 
у більшості випадків зумовлений зниженням скоротливої здатності міокарда лівого шлуночка. Приблизно у 30\% хворих, які перенесли ГІМ, розвивається серцева недостатність. Звичайно прогноз у таких пацієнтів є несприятливим, а летальність сягає 50\% протягом першого року [3]. Встановлено, що навіть після успішно ЧКВ, ризик несприятливих подій складає в перший рік $10 \%$ та щорічно - 5 \% впродовж чотирьох років після втручання (D. Erlinge, M. Radu, 2015). Тому залишається актуальним виявлення факторів, що мають вплив на тривалий прогноз у хворих 3 неадекватною відповіддю на дозовані фізичні навантаження та з перенесеним Q, QS IM після проведеного ЧКВ.

Мета дослідження: оцінка впливу та особливості перебігу постінфарктного періоду у хворих із перенесеним Q, QS інфарктом міокарда та супутньою артеріальною гіпертензією, які знаходились на етапі реабілітації та відновного лікування.

Матеріали та методи. Дослідження виконано на базі інфарктного відділення №2 ІваноФранківського обласного клінічного кардіологічного центру та кафедри внутрішньої медицини №2 та медсестринства Івано-Франківського національного медичного університету. За відсутності стійких госпітальних ускладнень пацієнтам було запропоновано участь у дослідженні при спостереженні в амбулаторних умовах протягом 6 міс. Критеріями незалучення в обстеження були: фракція викиду лівого шлуночка 40 \% i менше, велика аневризма лівого шлуночка, внутрішньо-порожнинне тромбоутворення, складні порушення серцевого ритму та провідності, блокада лівої ніжки пучка Гіса, серцева недостатність вище IIA стадії, порушення опорнорухової системи, гостре порушення мозкового кровообігу в анамнезі, декомпенсовані хронічні захворювання, онкологічні захворювання. Після отримання добровільної інформованої згоди пацієнти були залучені в обстеження.

Було обстежено 120 хворих із зниженою відповіддю на дозовані фізичні навантаження, із перенесеним Q, QS інфарктом міокарда та супутньою артеріальною гіпертензією, які знаходились на етапі реабілітації та відновного лікування, віком від 40 до 82 років (в середньому $(66,22 \pm 0,53)$ роки), із них 52 жінки та 73 чоловіки. Відповідно до методики відновлення коронарного кровотоку хворих було розпреділено на дві групи: 1-ша група - пацієнти, яким було виконане ендоваскулярне реперфузійне відновлення кровотоку шляхом стентування інфаркт залежної коронарної артерії (n=64), 2 група - пацієнти, які отримали ТЛТ (n=56). Досліджені групи були однорідними за віком, статтю, важкістю перебігу захворювання, тривалістю постінфарктного періоду.

Статистична обробка отриманих результатів проводилась за допомогою комп'ютерної програми STATISTICA-7 та пакета статистичних функцій програми «Microsoft-Excel» на персональному комп'ютері із застосуванням варіаційностатистичного методу аналізу. В ході роботи було вираховано середнє арифметичне М, середнє квадратичне відхилення $\delta$, середню помилку середньої арифметичної m, число варіанта (n), вірогідність різниці двох середньоарифметичних «р», величини $\mathrm{p}<0,05$ оцінювали вірогідними.

Результати дослідження та їх обговорення. Вік пацієнтів коливався від 40 до 82 років, в середньому $(66,22 \pm 0,53)$ роки, серед них було 52 жінки та 73 чоловіки. У 28,91 \% уже спостерігався IM в анамнезі. Із факторів ризику, крім АГ були наявні куріння у $14,51 \%$ з інтенсивністю $(18,51 \pm 2,23)$ пачок/років, у $59 \%$ - надмірна вага тіла з середнім індексом маси

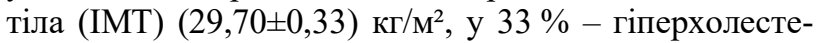
ринемія з середнім значенням $(5,03 \pm 0,01)$ ммоль/л. Також були діагностовані й інші супутні захворювання. Хронічна серцева недостатність у переважної більшості обстежених (63,3 \%) відповідала II - III ФК NYHA.

Клінічна картина IM проявлялась здебільшого ангінозним синдромом (81\%), хоча нерідко спостерігали атипові варіанти початку коронарного тромбозу (21\%), що ускладнювало діагностику. До госпіталізації у стаціонар у $43 \%$ пацієнтів мали місце прояви нестабільної стенокардії. Середня частота серцевих скорочень (ЧСС) склала $(87,51 \pm 1,02)$ уд/хв, a систолічний та діастолічний артеріальний тиск (САТ, ДАТ $)-(148,68 \pm 1,81)$ та $(87,78 \pm 0,87)$ мм рт. ст. У $43 \%$ пацієнтів виявлено порушення ритму, за типом шлуночкової (32 \%) та суправентрикулярної (25 \%) екстрасистолії, пароксизмів фібриляції передсердь (29 \%). Фібриляція шлуночків ускладнювала IM у 8 \%. У 11 \% ІМ розвинувся на тлі хронічної фібриляції передсердь, блокади різної локалізації спостерігали у $9 \%$. Рецидив IМ виявлено у $4 \%$ пацієнтів. Протягом перебування в стаціонарі хворі одержували препарати базової терапії, відповідно до існуючих протоколів лікування, окрім випадків, де ці засоби були протипоказані або неможливі через ускладнення. Статини, клопідогрель (тикагрелор), ацетилсаліцилову кислоту отримували 90 - $95 \%$ пацієнтів, інгібітори АПФ та $\beta$ блокатори - $94 \%$. Велику частку у призначеннях склали препарати цитопротекторної терапії - 63 \%.

Тривалість анамнезу АГ становила в середньому 15 - 20 років. Пацієнти обох груп мали надмірну масу тіла (IMT у 1 гр. - $(30,83 \pm 0,58) \kappa г / \mathrm{M}^{2}$, $\mathrm{p}=0,005$, у 2 гр. $\left.-(28,92 \pm 0,40) \kappa \Gamma / \mathrm{M}^{2}, \mathrm{p}=0,007\right)$. IM в анамнезі був у $23 \%$ пацієнтів 1гр., у $28 \%$ пацієнтів 2 гр.

Середні показники ЧСС, САТ та ДАТ серед пацієнтів обох груп незначно відрізнялись: у 1 гр. ЧСС - $(82,96 \pm 1,57)$ уд/хв, САТ - $(148,5 \pm 2,61)$ і ДАТ $(89,88 \pm 1,25)$ мм рт. ст; у 2 гр. ЧСС $(86,19 \pm 1,35)$ мм рт. ст., САТ $(150 \pm 2,47)$ і ДАТ $(89,77 \pm 1,20)$ мм рт. ст.

Згідно з даними ЕХО КГ різниця показників між 1 та 2 групами була недостовірною, окрім величини фракції викиду - $(46,06 \pm 0,45)$ i $(45,45 \pm 0,47) \%$, $\mathrm{p}<0,001$, та індексу маси міокарда - $(133,22 \pm 3,45) \mathrm{i}$ $(148,69 \pm 3,28) \Gamma / \mathrm{M}^{2}, \mathrm{p}=0,001$. У всіх пацієнтів переважали ознаки, притаманні концентричній гіпертрофії міокарда. 
Ускладнення в гострій фазі IM, \%

Таблиця 1

\begin{tabular}{|l|c|c|c|}
\hline \multicolumn{1}{|c|}{ Ускладнення } & Паціснти із ЧКВ, $\mathrm{n}=64$ & Пацієнти без ЧКВ, $\mathrm{n}=56$ & $\mathrm{p}$ \\
\hline ГСН III (Кіllip) & 9 & 25 & $<0,001$ \\
\hline ГСН IV (Кіllip) & 5 & 16 & 0,003 \\
\hline Надшлуночкові аритмії & 13 & 25 & 0,009 \\
\hline Шлуночкові аритмії & 18 & 13 & $<0,05$ \\
\hline Блокади & 11 & 20 & 0,034 \\
\hline Гостра аневризма шлуночка & 2 & 6 & $\mathrm{HД}$ \\
\hline Синдром Дреслера & 1 & 3 & НД \\
\hline Тромбоемболія & - & 1 & - \\
\hline Рання післяінфарктна стенокардія & 5 & 11 & 0,035 \\
\hline Механічні ускладнення & - & 3 & - \\
\hline Рецидив ІМ & 2 & 5 & НД \\
\hline
\end{tabular}

Як бачимо із даних, наведених у таблиці 1 , ранній післяінфарктний період у пацієнтів 1 групи характеризувався меншою кількістю ускладнень порівняно $з$ пацієнтами 2 групи. Тяжкі ускладнення, такі як гостра серцева недостатність (ГСН) III і IV (Killip), виникали значно рідше. Аритмогенна активність міокарда у пацієнтів 1 гр. виявлялась у 2 рази рідше після ЧКВ (за винятком періоду реперфузійного синдрому, одразу після відкриття коронарної артеpiï), порівняно із хворими 2 гр. А механічні (розрив міокарда, гострий НМК, відрив хорди) та тромбоемболічні ускладнення серед пацієнтів із проведеною ЧКВ не виявлялись зовсім. Інтервенційне відновлення прохідності коронарної артерії також служило профілактикою розвитку ранньої післяінфарктної стенокардії, яка, натомість, виникала у 11 \% пацієнтів без проведеної реперфузії. Рецидиви IM теж виникали у 2,5 раза частіше у хворих без ЧКВ.

У процесі лікування, у гострий період, функціональні показники системи кровообігу відновлювались швидше у хворих після ендоваскулярного втручання, про що свідчило переважання осіб з І ФК СН (29\% проти $11 \%, \mathrm{p}<0,001)$, на противагу суттєво нижчій частці хворих, в яких зберігався III- IV ФК (23 $\%$ проти $40 \%, \mathrm{p}=0,002)$.

30-денна летальність у пацієнтів обох груп суттєво не відрізнялась і становила у 1 гр. 3,17 \%, у 2 гр. $-5,74 \%(\mathrm{p}<0,05)$. Однак річне виживання було достовірно вищим у пацієнтів із ендоваскулярним втручанням - 92,60 \% у 1 гр. проти 85,63\% у 2 гр., p= 0,029. Це свідчить про те, що використання сучасних технологій лікування гострого коронарного синдрому, зокрема ЧКВ, може суттєво покращити подальший прогноз пацієнтів із IM в умовах коморбідності.

\section{Висновки:}

1. Перебіг у пацієнтів, яким було виконане ендоваскулярне реперфузійне відновлення кровотоку шляхом стентування інфарктзалежної коронарної артерії, суттєво впливало на зменшення ускладнень у гострому періоді інфаркту міокарда: рідше виникали порушення ритму та провідності, гостра серцева недостатність III - IV ст. (Killip) та механічні ускладнення. ЧКВ також $є$ профілактикою у розвитку ранньої післяінфарктної стенокардії.

2. Річне виживання пацієнтів після ендоваскулярного реперфузійного відновлення кровотоку шляхом стентування в 2,8 рази достовірно вище, ніж у пацієнтів без проведення реваскуляризації.

\section{References:}

1. Parxomenko AN, Lutaj YaM, Irkin OI, Belyj DA, Stepura AA, Kushnir SP i dr. Klinikoanamnesticheskaya xarakteristika i techenie gospitalnogo perioda zabolevaniya $u$ bolnyx molodogo vozrasta s ostrym koronarnym sindromom s elevaciej segmenta ST. Ukraïnskij Kardiologichnij Zhurnal. 2018; 4:31-39.

2. Shved MI, Levytska LV. Suchasni tekhnolohiyi vidnovnoho likuvannya khvorykh $\mathrm{z}$ hostrym koronarnym syndromom. K.: Vydavnychyy dim Medknyha, 2018. P.184.

3. 2017 ESC Guidelines for the management of acute myocardial infarction in patients presentingwith STsegment elevation The Task Force for the management of acute myocardial infarction in patients presenting with ST-segment elevation of the European Society of Cardiology // European Heart Journal. 2017. P.1-66. DOI: 10.1093/eurheartj/ehx393.

4. Guan W, Lu H, Yang K. Choosing between ticagrelor and clopidogrel following percutaneous coronary intervention: A systematic review and Meta-Analysis (2007-2017). Medicine (Baltimore). 2018; 97(43):12978.

5. Ibanez B, James S, Agewall S, Antunes MJ, Bucciarelli-Ducci C, Bueno H et al. 2017 ESC Guidelines for the management of acute myocardial infarction in patients presenting with ST segment elevation. Rev Esp Cardiol (Engl Ed). 2017; 70(12): 1082.

6. Rafique AM, Nayyar P, Wang TY, Mehran R, Baber $\mathrm{U}$, Berger PB et al. Optimal P2Y12 Inhibitor in Patients With ST-Segment Elevation Myocardial Infarction Undergoing Primary Percutaneous Coronary Intervention: A Network Meta-Analysis. JACC Cardiovasc Interv. 2016; 9(10):1036-1046.

7. Ibanez B, James S, Agewall S, Antunes MJ, Bucciarelli-Ducci C, Bueno H et al. 2017 ESC Guidelines for the management of acute myocardial infarction in patients presenting with ST-segment elevation: The Task Force for the management of acute myocardial infarction in patients presenting with ST-segment elevation of the European Society of Cardiology (ESC). Eur Heart J. 2018; 39(2):119-177. 
УДК 616.127-005.8+616.124.2+616.142-089

\section{ОЦЕНКА ТЕЧЕНИЯ ВОССТАНОВИТЕЛЬНОГО ЛЕЧЕНИЯ БОЛЬНЫХ ПОСЛЕ \\ ПЕРЕНЕСЕННОГО ИНФАРКТА МИОКАРДА С СОПУТСТВУЮЩЕЙ АРТЕРИАЛЬНОЙ ГИПЕРТЕНЗИЕЙ}

\section{О.М. Притуляк}

\author{
Ивано-Франковский национальный медицинский \\ университет, кафедра внутренней медицины №2 и \\ медсестринства, г. Ивано-Франковск, Украина, \\ ORCID ID: 0000-0001-5159-5209, \\ e-mail:dr.oprytuliak@gmail.com
}

Резюме. На сегодня сердечно-сосудистые заболевания (СС3) являются актуальной проблемой во всем мире. Согласно с данными ВО3, смертность от ишемической болезни сердца (ИБС) составляет 9,4 млн. в год или 16,5\% всех случаев смертности. Заболеваемость на ИБС в Украине составляет 1859,99, в Европейском регионе - 807,76 на 100 тис населения. Особенное внимание медиков среди ССЗ привлекает острый инфаркт миокарда (ОИМ), связанный с значительным распространением и высоким уровнем летальности среди лиц трудоспособного возраста. Ежегодно в Украине регистрируют почти 50 тис случаев ИМ, а смертность от этой патологии остается высокой. От ОИМ умирает 30\% пациентов, в то же время как в странах Запада - 5\%. В последнее время особенной актуальность приобрела проблема усовершенствования оказания неотложной медицинской помощи больным на ОИМ. Мировые тенденции в этом направлении склоняются к более широкому применении тромболитической терапии, интервенционного и кардиохирургического вмешательства. Эти вопросы нуждаются в детальном обосновании и анализе для улучшения условий предоставления медицинской помощи и уменьшения летальности среди больных с ОИМ. Наиболее эффективным методом лечения ОИМ является выполнение эндоваскулярной реперфузии миокарда путём стентирования инфарктзависимой коронарной артерии. Проведение ЧКВ способствует вероятному повышению фракции выброса левого желудочка, вероятному уменьшению конечного систолического объема, массы миокарда и индекса миокарда левого желудочка по сравнению с больными без проведённой реваскуляризации. Выполнение ЧКВ улучшает течение, прогноз и ход послеинфарктного кардиосклероза в больных после перенесенного Q, QS инфаркта миокарда и потому должно быть приоритетным направлением лечения таких больных.

Ключевые слова: острый инфаркт миокарда, артериальная гипертензия, ремоделирование, послеинфарктный период, стентирование.
UDC 616.127-005.8+616.124.2+616.142-089

\section{THE EVALUATION OF REHABILITATION TREATMENT COURSE FOR PATIENTS AFTER MYOCARDIAL INFARCTION WITH COMORBID ARTERIAL HYPERTENSION}

\section{O.M. Prytuliak}

Ivano-Frankivsk National Medical University, Department of Internal Medicine No 2 and Nursing,

Ivano-Frankivsk, Ukraine, ORCID ID: 0000-0001-5159-5209,

e-mail:dr.oprytuliak@gmail.com

Abstract. Currently, cardiovascular diseases (CVDs) are an actual problem in the whole world. According to the WHO data, ischemic heart disease (IHD) mortality is 9.4 million per year or $16.5 \%$ of all mortality cases. IHD morbidity is 1859.99 in Ukraine, 807.76 in the European Region per 100,000 population. Physicians pay special attention to acute myocardial infarction (AMI) among CVDs which is associated with significant widespread and high mortality levels among the workingage population. Every year about 50,000 MI cases are reported in Ukraine, and mortality for this pathology remains high. $30 \%$ of patients die from AMI, at the time, in Western countries this amount is 5\%. Lately, the problem of emergency medical aid improving for the patients with AMI got special relevance. World tendencies in this direction lean to the wider use of thrombolytic therapy, intervention, and cardiac surgery. These problems need detailed justification and analysis to improve conditions of medical aid and decrease of mortality among patients with AMI. Despite the achievements of modern interventional surgery, introducing of early invasive strategy, improved pharmacologic treatment options, improved quality and availability of medical aid, cardiovascular diseases in general and acute coronary syndrome (ACS) in particular remain a leading cause of mortality in developed countries and in Ukraine remaining a global healthcare problem.

According to modern guidelines for the management of patients with ACS, as MI with ST elevation (STEMI), as well as MI without ST elevation (nonSTEMI) of high, very high and intermediate risk, the using of early invasive treatment strategy is necessary, in order to provide maximum quick restoring of coronary blood flow. Despite the data of numerous randomized studies that proved early invasive treatment strategy and myocardial revascularization improves significantly not only ACS course, but also supports decrease in lethality indices. But the vast part of patients in our country get for one reason or another only conservative therapy.

Patients with ACS are a heterogenic group that dependent on disease type, present with significantly different clinical and hemodynamic characteristics of ACS and its consequences. In last years, frequency of invasive surgery in patients with STEMI increased significantly in our country, while revascularization for patients with non-STEMI remains on relatively low level. Taking the high frequency of conservative management strategy for such patients into account, optimization of pharmacologic therapy is one of main tasks for modern cardiology. 
The most effective treatment method for AMI is endovascular myocardial reperfusion via the stenting of the infarction-dependent artery. Performing PCI contributes in patients to probable left ventricular ejection fraction increase, probable end-systolic volume, myocardial mass and left ventricular myocardial performance index decrease compared to patients without done revascularization. PCI improves progression, prognosis, and course of post infarction cardiosclerosis in patients after Q-, QSwave myocardial infarction and therefore has to be a priority direction for the treatment of these patients.

Keywords: acute myocardial infarction, arterial hypertension, remodeling, post infarction period, stenting.

Стаття надійшла в редакцію 18.02.2020 p. 